\title{
THE END OF JUDICIAL CONSTITUTIONALISATION?
}

\begin{abstract}
Jo Hunt*
Summary: Conventional academic discourse, within both law and political science tells the story of how the European Court of Justice, though its judgments and judicial practices has 'constitutionalised' the EC Treaty, reformatting an intergovernmental bargain into a federal legal order. Many accounts have presented the Court as the heroic champion of integration, pushing the integrationist agenda forward when political channels are blocked, and integration through political and legislative means stalled. This article considers whether, in the period following the rejection of the formal constitutionalisation project, it is appropriate to look to the Court to step in and continue the drive towards further, deeper integration, and to further develop and entrench its own constitutional role. It is argued that such a view should not be too readily accepted, as it could be seen as affording too great a respect for the rhetoric of judicial constitutionalisation, which is presented as both fallacious and unhelpful, and as affording insufficient recognition of the realities of the Court's role as a legal institutional actor operating within a complex context in which it has limited autonomy. The paper reviews existing academic assessments of the constitutionalising role of the Court, before considering the significance of the recently proposed Treaty changes to the role and position of the Court, which leads to a consideration of the limited prospects for continued judicial 'constitutionalisation' in the future.
\end{abstract}

\section{Introduction}

Conventional academic discourse, within both law and political science tells the story of how the European Court of Justice, though its judgments and judicial practices has 'constitutionalised' the EC Treaty, reformatting an intergovernmental bargain into a federal legal order. This rhetoric of constitutionalisation has itself been long used by the Court. Within academic accounts, emphasis has also been placed on the constitutional adjudicatory role the Court plays amongst the other functions it performs, and indeed, there have been calls for reform of the judicial architecture so as to assign it a purely constitutional role. Additionally, conventional accounts have presented the Court as the heroic champion of integration, pushing the integrationist agenda forward when political

\footnotetext{
* Dr Jo Hunt, Cardiff Law School, Huntj@cardiff.ac.uk
} 
channels are blocked, and integration through political and legislative means stalled. On one level then, in the period following the rejection of the formal constitutionalisation project, it is perhaps not inappropriate to look to the Court to step in and continue the drive towards further, deeper integration, and to further develop and entrench its own constitutional role. However, it is argued that such a view should not be too readily accepted, as it could be seen as affording too great a respect for the rhetoric of judicial constitutionalisation, and insufficient recognition of the realities of the Court's role as a legal institutional actor operating within a complex context in which it has limited autonomy.

\section{1: Constitutionalisation by the Court}

All students of EU law are steeped in the canon of familiar cases which are strung together in a legal narrative which tells the story of the Court of Justice's constitutionalisation of the Treaty.

Starting with Van Gend en $\operatorname{Loos}^{1}$ and Costa $v$ Enel, ${ }^{2}$ it tells how the Court, through its judicial pronouncements, created a set of principles which structure the EU legal order. Through these early, crucial interventions, the Court recognised the possibility of direct effect of Community law, thereby creating a framework in which rights derived from Community law could, under certain circumstances, be relied on directly before national courts. Further, these Community law rights are to be regarded as supreme, thereby trumping conflicting national law, of whatever status. The Court subsequently developed a set of legal principles on the operation and effectiveness of remedies for the breach of EC law at national level, going so far as to construct a right to damages for individuals in the event of a sufficiently serious breach of EC law by the Member States. ${ }^{3}$ Additionally, the Court was to expand on the review of legality of Community acts with which it was charged under Article 230 EC Treaty, identifying a set of overarching 'general principles', including fundamental human rights, which could operate as legally enforceable constraints on the exercise of power by the EC institutions, and also by the Member States in the context of their application of EC law. In this way, it developed itself a role as a court of constitutional review, famously proclaiming that the EC 'is a Community based on the rule of law, in as much as neither its Member States nor its institutions can avoid a review of the question of whether the measures adopted by them are in conform-

1 Case 26/62 Van Gend en Loos v Nederlandse Administratie der Belastingen [1963] ECR 1.

2 Case 6/64 Costa $v$ Enel [1964] ECR 585.

3 Joined Cases C-6/90 and C-9/90 Francovich and Others $v$ Italian Republic [1991] ECR I-5357. 
ity with the basic constitutional charter, the Treaty'. ${ }^{4}$ Added to this has been the Court's role in determining the extent of the EC's internal and external competences, fixing the outer limits of the legitimate exercise of the EC's attributed powers.

The Court then may be seen as having been a motor of integration, driving the Community ever onward towards further and deeper integration. The steady accretion of constitutionalising case law over the years may be presented as the inevitable achievement of the "certaine idée de l'Europe ${ }^{5}$ coded into its legal system, and as according with some blue print to which the Court is tirelessly working. However, such an account has been demonstrated as being based on assumptions about the Court and the law which are fallacious, and unhelpful. Such assumptions, it will be shown in this section, are fallacious, as they overstate the integrative capacity of law, and posit a view of the case law as progressing ineluctably to an inevitable constitutional finalité. They are also unhelpful, in that the rhetoric of constitutionalisation ascribed to the Court's activities was taken as the starting point in the negotiations and drafting work which lead to the Treaty Establishing a Constitution for the European Union, a process which revealed the judicial constitution to be out of step, and irreconcilable with social and political reality. This point will be considered in section 2. The constitutional significance for the Court of the Reform Treaty mandate is examined in section 3 , before a consideration of the future of judicial constitutionalisation is provided in section 4 .

That caution should be exercised in accepting the simplified constitutional narrative was a point raised over two decades ago by Shapiro. He launched a critique on conventional lawyerly accounts of constitutionalisation by the Court as being 'constitutional law without politics' which

presents the Community as a juristic idea; the written constitution as a sacred text; the professional commentary as a legal truth; the case law as the inevitable working out of the correct implications of the constitutional text; and the constitutional court as the disembodied voice of right reason and constitutional teleology. ${ }^{6}$

Picking up this critique, Shaw challenged the assumption underpinning many accounts of the Court which posits 'an immutable link between law and legal processes and integration', where the latter 'is conventionally if somewhat simplistically understood as a process leading

\footnotetext{
4 Case 294/83 Parti Ecologiste 'Les Verts' v Parliament [1986] ECR 1339, 1365.

5 The term used by a former judge of the European Court of Justice, P Pescatore, 'The Doctrine of Direct Effect: An Infant Disease of Community Law' (1983) 8 EL Rev 155, 157.

6 M Shapiro, 'Comparative Law and Comparative Politics' (1979-80) 53 Southern California Law Review 537, 538.
} 
towards greater centralisation of governmental functions'. ${ }^{7}$ Shaw asserts that 'the role of law and of the Court in feeding integration processes is taken for granted, and frequently overstated', ${ }^{8}$ whilst the true picture is significantly more complex. Wincott similarly, critiques the 'inevitability of the constitutionalisation of Community law' apparent in some doctrinal accounts, which writes out politics and agency, and assumes a 'linear progression towards ever closer union'. ${ }^{9}$ Clearly, Shaw and Wincott are not denying that the Court has handed down judgments of constitutional significance, but they highlight that attempts to present this as an inevitable, inexorable move towards further integration would be wrong. And an easy reliance on the court as a constitutional champion is misplaced.

A major corrective to conventional constitutional accounts has been in the growth of work which focuses on the environment in which Court operates, on its interlocutors, ${ }^{10}$ and, importantly, on their interrelationships. Wincott for example, attacks approaches which 'assume that the statement of a legal principle by the Court is tantamount to the constitution of a new legal reality, rather than understanding it as part of a policy making process ${ }^{\prime 11}$ and further demonstrates that the Court has by no means been in full control of the environment in which it operates. ${ }^{12}$ Similarly, Armstrong's approach reflects an understanding that the Court's jurisprudence 'should not be conceived of in terms of fidelity to a foundational Member State bargain, nor to a preordained teleology of integration, but rather to an attempt to mediate between law and its environment'. ${ }^{13}$ In this environment, the Court's identity as a judicial institution is paramount : to ensure its legitimacy qua judicial authority, it has to be seen to be operating according to legal processes and norms of appropriateness. The Court's rulings have to fulfil certain basic requirements so as to satisfy the demands of 'internal', or legal legitimacy, ${ }^{14}$

\footnotetext{
7 J Shaw, 'Introduction' in J Shaw and G More (eds), New Legal Dynamics of European Union (Clarendon Press, Oxford 1995) 3.

8 Ibid 4.

9 D Wincott, 'Political Theory, Law and European Union' in Shaw and More (n 7) 298.

10 JHH Weiler, 'A Quiet Revolution: The European Court of Justice and Its Interlocutors' (1994) 26 Comparative Political Studies 510.

11 Ibid 299.

12 D Wincott, 'The Role of Law or the Rule of the Court of Justice? An 'Institutional' Account of Judicial Politics in the European Community' (1995) 2 Journal of European Public Policy 583.

13 KA Armstrong, 'Legal Integration: Theorizing the Legal Dimension of European Integration' (1998) 36 Journal of Common Market Studies 155, 156.

14 See further J Bengoetxea, N MacCormick and L Moral Soriano, 'Integration and Integrity in the Legal Reasoning of the European Court of Justice' in G de Búrca and JHH Weiler (eds), The European Court of Justice (OUP, Oxford 2001).
} 
which would include the sources used by it in reaching its judgment, and the nature of its reasoning processes. The Court's immediate legal institutional environment is to be seen as limiting and structuring: '[I]t structures access to the courts and the formalities of appearing before the ECJ. It structures the substantive forms of argument which can be raised and the procedures for doing so. It structures the normative construction of facts presented to the ECJ'. ${ }^{15}$ An account of the Court's case law which is more in line with the identity of the Court as a judicial institution, operating according to judicial norms is provided by former Judge at the Court, David Edward: '[T]he judge must proceed from one case to another, seeking, as points come up for decision, to make the legal system consistent, coherent, workable and effective'. ${ }^{16}$

A judgment which is internally justifiable according to legal norms will not necessarily be externally justifiable, that is, be considered ethically, politically or ideologically acceptable ${ }^{17}$ by other actors. That is not to say that the Court operates in an apolitical vacuum, of course. External forces may well prove important, but these have to be fed into, and responded to, within the context of the Court operating as a legal institution. The Court operates within a dense network of policy actors, including referring courts, national supreme and constitutional courts, the Commission, Advocates General, Member States governments and litigants. Some of these actors have a particularly privileged place in the Court's institutional structure, enabling them ready access to participate in cases, presenting the Court with their own perspectives on the 'correct' response in particular case, and feeding into an ongoing, iterative process of policy, and polity development. Important recent work has seen attention turn to assessments of the contributions made to the direction of the Court's case law by the submissions of Advocates General, ${ }^{18}$ as well as of the Member State governments, through the observations made before the Court, ${ }^{19}$ in a range of policy sectors. However, it is perhaps significant and reflective of the continued dominance of the autonomous, heroic view of the Court to note how little attention lawyers have placed on the important interchanges which have taken place between Commission and Court ${ }^{20}$ since Stein identified the former's apparent contribution

\footnotetext{
15 KA Armstrong, 'Conceptualizing the European Union: The Contribution of New Institutionalism' (1998) (unpublished paper, on file with the author).

16 D Edward, 'Judicial Activism: Myth or Reality?' in AIL Campbell and M Voyatzi (eds), Legal Reasoning and Judicial Interpretation of European Law (Trenton, Gosport 1996) 66-7.

17 Bengoetxea, MacCormick and Moral Soriano (n 14) 61.

18 N Burrows and R Greaves, The Advocate General and EC Law (OUP, Oxford 2007).

19 M-P Granger, 'When Governments Go To Luxembourg: The Influence of Governments on the European Court of Justice' (2004) 29 EL Rev 1. Review 1

20 But see, in the field of the free movement of goods, K Alter and S Meunier-Aitsahalia, 'Judicial Politics in the European Community: European Integration and the Path-break-
} 
in $1981 .{ }^{21}$ Reviewing the then extant corpus of constitutionalising cases, Stein demonstrated that in all but two of the eleven cases, the Court's judgments accorded with the views presented by the legal service of the Commission. Indeed, it was the Commission which had introduced to the Court in Van Gend the idea of the Community system as a new legal order, and had argued strongly for the recognition of direct effect of Community law provisions. In fact, the Court stopped short of the Commission's position in this case, which sought acknowledgement of the supremacy principle, though of course this was later to come in Costa. Stein views the Court as having been 'led' by the Commission, their close alliance 'probably alleviat[ing] some of the concern members of the Court may have felt regarding the legitimacy and acceptance of its rulings'. ${ }^{22}$ All this should not be taken as assuming that the Court is in some way captured by the political actors in the field, it is not the agent to their principal, simply, it will be aware of its political environment, of what is presented as politically appropriate, and may seek to incorporate such views when exercising its judicial functions.

Just as there were particular views held by the members of the Legal Services of the Commission, it is of course relevant to consider the views held and approaches taken by the members of the Court at a particular time. Sometimes these may well coalesce around une certain idée de l'Europe which is shared by certain other political actors. Certain views may be deeply embedded in the system, such as the attainment of effectiveness and coherence in the legal order, whilst others may be more policy specific, reflecting particular political and economic ideologies. Such principles and values could include for example, the achievement of the goal of market integration, fair competition, and respect for family life. ${ }^{23}$ However, such principles should not necessarily be seen as static, or all powerful, as they respond to changing values of the time, and also to the shifting composition of the Court. The importance of judicial backgrounds was averred to by another former Judge of the ECJ, Ulrich Everling, who, in the mid 1980s, suggested the Court's 'increasingly cau-

ing Cassis de Dijon Decision' (1994) 26 Comparative Political Studies 535; and, in the field of employment protection, J Hunt, 'The Court of Justice as a Policy Actor: The Case of the Acquired Rights Directive' (1998) 18 LS 336.

21 E Stein, 'Lawyers, Judges and the Making of a Transnational Constitution' (1981) 75 AJIL 1.

22 Ibid 24.

23 As witnessed in a number of recent citizenship/free movement cases such as Case C413/99 Baumbast $v$ Secretary of State for the Home Department [2002] ECR I-7091; Case C60/00 Carpenter $v$ Secretary of State for the Home Department [2002] ECR I-6279; however, the model of the family being protected is a particularly traditional one, cf the treatment of gay partnership rights: Case C-249/96 Grant $v$ South-West Trains [1998] ECR I-621; Joined Cases C-122/99 P and C 125/99 P D and Sweden v Council [2001] ECR I-4319. 
tious' approach to laying down general principles was in part due to 'the arrival of judges from the common law tradition schooled in case law and inclined to a pragmatic approach'. ${ }^{24}$

A further corrective offered by Shaw to the conventional constitutionalisation approach was her recognition of disintegration in the EU legal order, the counterpoint to increasing centralisation, apparent, for example, in the fragmented pillars of the Union, and, within the EC pillar, in the space for difference and diversity reflected in the norms, tools and techniques of the law. These include the principle of subsidiarity, but also in longer standing elements, such as the space afforded for national variation by directives. Such elements are presented 'not as exceptions to an integrationist norm, but as autonomous facets of the whole'. ${ }^{25}$ Ten years on from Shaw's contribution, the disintegrative elements in the EU order are more pronounced, or at least, more acknowledged by legal commentators, disintegration becoming normalised, as accounts of the Court and the legal order mature. Extensive work for example has been undertaken examining the open method of co-ordination as a governance technique ${ }^{26}$ as an alternative to legal regulation, and incorporating it into our models of the EU legal order, though of course, steering through soft law is by no means new phenomenon. ${ }^{27}$ The assumption that the Court seeks 'to expand the scope of supranational governance' whilst claimed by Stone Sweet to be 'implicitly shared by nearly all legal scholars' ${ }^{28}$ is increasingly untenable, as seen by the cases in which it has resisted centralising tendencies. ${ }^{29}$ Nor, it should be noted, has the Court pursued all lines so as to reinforce its own constitutional role. It famously has chosen not to facilitate the route to the Court for direct challenges to the legality of Community measures for 'non-privileged' actors under Article 230 EC Treaty. As Schepel and Blankenburg point out, it has 'refrained from turning Article [230] into a vehicle of general constitutional review'. Further,

24 U Everling, 'The Court of Justice as a Decision-making Authority' (1983-4) 82 Michigan Law Review 1294, 1301.

25 J Shaw, 'European Legal Studies in Crisis? Towards a New Dynamic' (1996) 16 OJLS 232, 241 (emphasis in the original).

26 See, for example, J Scott and D Trubek, 'Mind the Gap: Law and New Approaches to Governance in the European Union' (2002) 8 European Law Journal 1 (introduction to a special edition on new governance); G de Búrca and J Scott (eds), Law and New Governance in the EU and US (Hart Publishing, Oxford 2006).

27 K Wellens and G Borchardt, 'Soft Law in the European Community Law' (1989) 14 EL Rev 267.

28 A Stone Sweet, 'European Integration and the Legal System' in T Börzel and R Cichowski (eds) The State of the European Union, Volume 6: Law Politics and Society (OUP, Oxford 2003) 25.

29 See Opinion 2/94 Accession to the ECHR [1996] ECR I-1759; Case C-376/98 Germany $v$ Parliament and Council (Tobacco Advertising) [2000] ECR I-8419. 
[a] court that wants to engage in lawmaking usually transforms its courtroom into a legislative assembly - allowing class actions, public interest litigation, popular constitutional complaints, Brandeis briefs. The most striking feature of the ECJ's case law is that it has resisted all of these. ${ }^{30}$

In short, 'constitutionalisation' may be a consequence of the activities of the Court, a useful label ascribed to the various judgments which have had a structuring impact on the nature of the EU legal order, but constitutionalisation should not be seen as some inherent logic within the legal system, driving the Court - and the integration process - ever forward.

\section{2: The Court under the Constitutional Treaty}

The conventional rhetoric of judicial constitutionalism - and the strength of the Court- created constitution was to be tested by the attempts to formalise certain key aspects under the Constitutional Treaty. The Constitutional Treaty would also affect in a number of competing ways the Court's role and status as the supreme and constitutional court for the EU. However, compared to the political institutions, the Court received very limited attention in the process of drafting and adopting the Constitutional Treaty. It was not directly represented in the Convention framework, none of the Working Groups focused exclusively on the Court and its future role, though certain of the Court's members were involved (in a personal capacity) in presenting evidence to the Working Groups which fed into the draft Treaty presented by the Convention to the Intergovernmental Conference. Somewhat belatedly, and in response to concerns raised in the Convention's plenary discussion about the limited attention paid to the Court, a 'Discussion Circle' on the Court was established. The Circle was given a very limited period in which it meet and present its report, ${ }^{31}$ and, with the odd exception, the suggested areas for its attention were of relatively limited constitutional significance. These issues included possible changes to the procedure for appointing the Judges and Advocates-General; changes to the decision rules for amendments to the Court's rules of procedure; consideration of the names of the Courts; the fining power of the Court of Justice where states fail to comply with its judgment; and of greater constitutional significance, the standing rules for individual applicants to bring actions in judicial review before the Courts.

30 H Schepel and E Blankenburg, 'Mobilizing the European Court of Justice' in de Búrca and Weiler (n 14) 41.

31 It met on four occasions in February and March 2003 before presenting its main report, CONV 636/03, on 25 March 2003. 
The creation of the Constitutional Treaty necessarily involved attempts to formalise and concretise certain constitutional doctrines which formerly existed solely in the Court's jurisprudence (and 'received' with varying degrees of enthusiasm and consistency by the national courts), and which had never, as such, been held up to a binary accept/reject determination on the part of Member State governments. It is in relation to the principle of primacy, or supremacy, where we see the most glaring mismatch between the conventional rhetoric of judicial constitutionalism clashing with other legal and political realities. A privileging of the Court of Justice's jurisprudence presents Community law supremacy as an essential, fundamental and unconditional aspect of the legal order. The Court of Justice of course ruled in Internationale Hangelsgesellschaft ${ }^{32}$ that provisions of Community law held supremacy over national constitutional provisions. A majority of Member States however would not share this view. Their courts' understandings of supremacy are conditional, and the Court of Justice's rulings are refracted through their own national constitutional lenses. ${ }^{33}$ Some indeed have had the opportunity to make explicit their rejection of EC law supremacy over their constitutions. ${ }^{34}$ According to the conventional constitutional rhetoric however, such positions by Member State courts are regarded as temporary aberrations, with the expectation that they will eventually fall into line. Weiler for example spoke of the 'evolutionary character' of the process of the incorporation of the principle by the national supreme courts. ${ }^{35}$ What such views fail to capture is that the conditionality attached to supremacy is not a temporary aberration, but a permanent feature of the EU constitutional order. The drafting history of the supremacy clause is instructive - with the first drafts of the article providing that the law of the EU constitution would be supreme over the law and constitutions of the Member States. The final text, contained in Article I-6 of the Constitutional Treaty, meanwhile provided that 'the Constitution and law adopted by the institutions of the Union in exercising competences conferred on it shall have primacy over the law of the Member States'. Despite a statement annexed

32 Case 11/70 Internationale Handelsgesellschaft $v$ Einfuhr- und Vorratsstelle fur Getreide und Futtermittel [1970] ECR 1125.

33 On the French Constitutional Court's decision on the constitutionality of possible ratification of the Constitutional Treaty, see L Azoulai and FR Agerbeek, 'Conseil constitutionnel (French Constitutional Court), Decision No. 2004-505 DC of 19 November 2004, on the Treaty establishing a Constitution for Europe' (2005) 42 CML Rev 871. See also, of course, the German Federal Constitutional Court's contribution to the issue, eg Re Wünsche Handelsgesellsschaft [1987] CMLR 225 and Brunner $v$ The EU Treaty [1994] CMLR 57.

34 See the ruling of the Polish Constitutional Tribunal on Poland's Membership in the EU (The Accession Treaty), K18/04, 11 May $2005<$ http://www.trybunal.gov.pl/eng/summaries/documents/K_18_04_GB.pdf> accessed 22 July 2007.

35 JHH Weiler, 'The Community System: The Dual Character of Supranationalism' (1981)

1 YBEL 267, 276. 
to the Constitutional Treaty that the provision was simply a codification of existing case law, its absence certainly allowed for an ambiguity not provided for in the Court's own jurisprudence.

Of course, that ambiguities over the scope of the supremacy principle were present in the negotiated Treaty outcome is unsurprising. The Court's version of supremacy is only one version of this story, told for particular purposes. Whilst this version has tended to be privileged and reified in EU law writing, it simply does not capture the complexity, the mixed 'in between-ness' of the EU constitutional order. An alternative version is gaining ascendancy in academic writing which draws on the idea of constitutional pluralism, presenting the relationships between the EU and national orders as 'pluralistic rather than monistic, and interactive rather than hierarchical'. ${ }^{36}$ Fixing a matter such as the primacy of EU law over national constitutional provisions definitively, and unconditionally in a constitution would, according to Shaw, 'require something akin to a constitutional revolution in Europe and in the Member States'. ${ }^{37}$ Rather than taking the constitutionally impossible step of concretising the position of the Court and its legal order, removing the indeterminacy of the system, and establishing definitively the status of the Court and the effects of its rulings, the settlement reached in the Constitutional Treaty left these issues open and indeterminate, rejecting the maximalist view of the Court's constitution.

As well as containing a denial of the Court's conception of supremacy, the Constitutional Treaty also rejects the view that the Court unequivocally holds kompetenz-kompetenz: the competence to determine the limits of EU competence. The concern, reflected in the German constitutional court's challenge in Brunner ${ }^{38}$ is that in exercising its review powers, the Court of Justice may countenance an extension to the Community's powers as set out in the Treaty. Such an extension could only be validated by the Member States, as it is they who remain, according to the German constitutional court, the 'Masters of the Treaty'. Under the Constitutional Treaty, the exercise of the Union's competences was to continue to be subject to the operation of the principles of subsidiarity and proportionality, with an obvious emphasis on preferring greater ex ante monitoring of its operation (through for example, the new role provided for national parliaments) over ex post legal action. The attempted demarcation of the nature and scope of competences in the Constitutional Treaty could not however be expected to reduce the incidence of actions alleging a trans-

\footnotetext{
36 N MacCormick, Questioning Sovereignty (OUP, Oxford 1999) 118. See also N Walker, 'The Idea of Constitutional Pluralism' (2002) 65 Modern Law Review 317.

37 J Shaw, 'Legal and Political Sources of the Treaty Establishing a Constitution for Europe' (2004) Northern Ireland Legal Quarterly 214, 237.

38 See $\mathrm{n} 33$.
} 
gression of the limits of competence, nor would it have made it any easier for the Court to resolve. Any extension to explicitly conferred competences by the Court appears ruled out by Article I-11 Constitutional Treaty, which provides that competences not explicitly conferred on the EU by the Constitutional Treaty remain with the Member States. Potential problems would however arise were the Court required to rule on the very question of whether or not competence in a particular case has, or has not been handed over, rather than simply assessing whether the exercise of power falls within clear cut categories.

However, at the same time as these denials of the conventional constitutional rhetoric, the Constitutional Treaty contained a number of aspects that would have contributed to an entrenchment and further development of the Court's role as a Constitutional Court for the EU. The first of these is the incorporation in Part II of the Constitutional Treaty of the EU Charter of Fundamental Rights. The Charter, adopted in a non-binding declaratory form in 2000, would - under the Constitution - have binding force, though certain of its provisions (but by no means all) have previously been recognised and enforced by the ECJ as part of an overarching set of 'general principles of law'. Its inclusion may be perceived as desirable from the perspective of enhancing legitimacy, clarity and transparency within the EU order, and it certainly throws into relief the European Court's constitutional function in ensuring the respect of such rights. The Court's tasks under the Charter would be by no means straightforward. The Court would be required to identify justiciable 'rights' and non-justiciable 'principles', and there may be the potential for dissonance between the EU's human rights jurisprudence, and that of the ECHR ( recognised under the Constitution as general principles of law); and for confusion to arise over the overlap between rights expressed in Part II, and those contained elsewhere in the Constitution and in Union law.

The Constitutional Treaty gave the fundamental rights responsibility of the Court an extra dimension with the 'depillarisation' of the existing EU order, and the extension of the Court's jurisdiction to the Area of Freedom, Security and Justice, ${ }^{39}$ which incorporates the former EC Treaty provisions on visas, asylum and immigration, and the Police and Judicial Co-operation pillar. Notably, the standard preliminary reference procedure would be available in these areas, rather than the existing system which allows States to exclude the opportunity entirely (in respect to Police and Judicial Co-operation), or it restrict to the highest courts (in

39 Though remaining to all intents and purposes excluded from ruling in respect of the Common Foreign and Security Policy, see M-G Ketvel, 'The Jurisdiction of the European Court of Justice in Respect of the Common Foreign and Security Policy' (2006) 55 ICLQ 77. 
respect to the field of visas, asylum and immigration). Bringing these areas within the general jurisdiction of the ECJ is significant from a constitutional, fundamental rights perspective simply because it is in respect to the subject matter of these areas that concerns about fundamental rights and freedoms may be considered particularly acute. This is reflected in particular by the revised form of Article $234 \mathrm{EC}$, which declares that 'in a case pending before a court or tribunal of a member state with regard to a person in custody, the Court shall act with a minimum of delay'. ${ }^{40}$

Clearly, human rights issues may find their way before the Court through preliminary references from national courts. Another route is through judicial review, and the direct action for annulment, found in the Constitutional Treaty at Article III-365. In a note submitted to the Working Group on the Charter/ECHR in September 2002, Advocate General Jacobs expressed the view that even if the proposed inclusion of the Charter were to go ahead, 'the fundamental rights so recognised or referred to, risk remaining an empty shell if there is no system of judicial remedies which guarantees the effective protection of those rights' ${ }^{41}$ The Advocate General had presented strident calls for a new interpretation of the standing rules already, in his judicial capacity, most notably in the case of Unión des Pequeños Agricultores. ${ }^{42}$ In its judgment in that case, the Court of Justice confirmed the existing rules, and failed to endorse the Advocate General's new test, stating that if any change to the standing rules were necessary, then change must come from the Member States in the context of a Treaty revision, rather than from the Court itself.

Thus, the issue appeared on the Convention's agenda. Whilst the weight of academic opinion has tended towards favouring a liberalisation of the standing rules, particularly in the light of the introduction of the Charter so as to facilitate individuals' access to the Court, it would be a mistake to assume that there is unqualified support for this development across the EU. ${ }^{43}$ Member State traditions in relation to judicial review are quite different. As one current Judge of the Court, speaking in a personal capacity observed, whilst challenges to the administrative acts of the executive are generally permitted across the Member States, the idea of allowing for the annulment of general legislative measures passed in accordance with democratic procedures is, according to some legal traditions, 'almost revolting'. Article III-365 CT makes some rather tokenistic

\footnotetext{
40 Article III-369 Constitutional Treaty.

41 F Jacobs, 'Note to the Working Group on the Charter/ECHR: Necessary Changes to the System of Judicial Remedies' WG II-WD $20<$ http://european-convention.eu.int/docs / wd2/3222.pdf> accessed 22 July 2007.

42 Case C-50/00 P Unión des Pequeños Agricultores v Council [2002] ECR I-6677.

43 M-P Granger, 'Towards a Liberalisation of Standing Conditions for Individuals' (2003) 66 MLR 124.
} 
gestures towards a liberalisation of standing, confirming that in principle individuals can challenge any administrative or general legislative measure, though removing the requirement of individual concern in respect of self-executing non-legislative acts. Apart from these minor advances in the standing rules under the Constitutional Treaty, the restrictive force of the standing rules remained. Perversely, as Craig has noted, the Constitution 'exhorts the Member States to provide sufficient legal protection in the field of Union law, while saying nothing about any similar obligation on the Union concerning access to justice'. ${ }^{4}$

Thus the Constitutional Treaty would have gone some way to entrenching the constitutional functions of the Court, and, in tandem with the consequences of the various changes to introduced by the Nice Treaty, ${ }^{45}$ could be expected to contribute to an increasing specialisation of the Court's constitutional role. ${ }^{46}$ At same time, the process of negotiating the Constitutional Treaty and formalising the Court's constitutionalised doctrines challenged its constitutional rhetoric. Such damage was done regardless of whether ratification ultimately took place.

\section{3: The Court under the Reform Treaty}

Of course, ratification by all Member States was not possible. Whilst a majority successfully completed the ratification process, the 'no' votes in the Netherlands and France halted the process and led to two-year 'period of reflection'. In June 2007, the Heads of State and Government, meeting as the European Council, agreed on a way forward that would see reform of the existing Treaties, providing for the maintenance of many of the institutional innovations contained in the Constitutional Treaty, but which would see some of the more controversial elements removed. The European Council agreed on a mandate ${ }^{47}$ to form the basis and framework for negotiations in an Intergovernmental Conference, commencing in July 2007. That a way out of the constitutional impasse could be found

44 P Craig, 'What Constitution does Europe Need? The House that Giscard Built: Constitutional Rooms with a View' (2003) The Federal Trust Constitutional Online Paper Series No 26/03 <http://www.fedtrust.co.uk/uploads/constitution/26_03.pdf> accessed 22 July 2007.

45 Such as the potential for the Court of First Instance (which would have been renamed the 'General Court' under the Constitutional Treaty) taking on jurisdiction for Article 234 EC references.

46 For discussions of the possibility of reserving an exclusive constitutional jurisdiction to the European Court of Justice, see eg B Vesterdorf, 'A Constitutional Court for the EU?' (2006) 4 International Journal of Constitutional Law 607.

47 Council of the European Union, Presidency Conclusions (Brussels, 23 June 2007) 11177/07 CONCL 2. For the first draft of the Reform Treaty, see CIG 1/07 (Brussels, 23 July 2007); see also http://www.consilium.europa.eu/cms3_fo/showPage. asp?id=1297\&lang=en . 
is in many respects down to Germany's President Angela Merkel's careful diplomacy. With Germany's six-month Presidency of the European Council coming to an end, Portugal has taken over the task of managing the move to the adoption of a formal Reform Treaty document. The proposed time scale is ambitious. When presenting its Presidency Programme, Portugal's Prime Minister Socrates stated a commitment to having agreement on the text of the Treaty by the middle of October 2007.

According to the IGC Mandate, '[t]he constitutional concept, which consisted in repealing all existing Treaties and replacing them by a single text called "Constitution" is abandoned'. ${ }^{48}$ The envisaged Reform Treaty will retain the current two-Treaty approach, bringing amendments to both the Treaty on European Union, and to the EC Treaty, which will be renamed the Treaty on the Functioning of the European Union. The language of constitutionalism is rejected, as are those aspects from the Constitutional Treaty perceived by some as redolent of statism: the motto, flag and anthem, and the nomenclature of 'Union Minister for Foreign Affairs', now renamed the 'High Representative of the Union for Foreign Affairs and Security Policy'. Amendments to the form and functioning of the institutions, necessary to ensure a more effective operation of an ever-expanding Union are, by and large maintained, ${ }^{49}$ as are the extensions to the Court's jurisdiction over the Area of Freedom, Security and Justice. The concern with competences and their proper exercise is apparent. A Declaration is proposed which reinforces the principle of conferral, and which additionally acknowledges for the first time that the Member State governments, through Treaty revision may both increase and reduce competences conferred by them on the Union.

The provision on the primacy of Union law will not appear in the main text of the Treaties, though a Declaration is proposed, the text of which will provide that ' $[t]$ he Conference recalls that, in accordance with the well-settled case law of the EU Court of Justice, the Treaties and the law adopted by the Union on the basis of the Treaties have primacy over the law of the Member States, under the conditions laid down by the said case-law'. As with the formulation contained in the Constitutional Treaty, there is no explicit mention of the supremacy of EU law over national constitutions. The reference to the primacy of the law of the Treaties meanwhile does suggest that the supremacy principle should not be seen as limited to the law of the former community pillar but extends across the actions of the Union.

48 Presidency Conclusions ANNEX 1 [1].

49 Although concessions to certain States appear necessary on the introduction of new voting rules in Council. 
A more significant omission from the main body of the Treaties is that of the EU Charter of Fundamental Rights, though the envisaged reformed TEU will cross-reference it, and will state that it will have legally binding force, and the same legal value as the Treaties. The Charter is to be re-enacted by the institutions, and published in the Official Journal. However, a set of declarations and protocols seek to limit the impact of the Charter, and the use which can be made of it by the Court. The UK government's position on the legal status of the Charter has hardened considerably since its agreement to the Constitutional Treaty. Under a proposed Protocol, the UK seeks to limit the legal effects of the Charter. The Protocol provides:

Article 1

1. The Charter does not extend the ability of the Court of Justice, or any court or tribunal of the United Kingdom, to find that the laws, regulations or administrative provisions, practices or action of the United Kingdom are inconsistent with the fundamental rights, freedoms and principles that it reaffirms.

2. In particular, and for the avoidance of doubt, nothing in...the Charter creates justiciable rights applicable to the United Kingdom except in so far as the United Kingdom has provided for such rights in its national law'.

It has been reported that the UK government became particularly concerned with the potential for the Charter, and its interpretation by the Court, to challenge national labour law, requiring extensions to the rights available at national level. This position was no doubt sharpened following recent Advocates Generals' opinions which consider the right to strike, arising in the context of attempts to assure respect for employment terms and conditions by service providers making use of the free movement of services provisions. ${ }^{50}$ Significantly, Advocate General Maduro in his opinion recognised the rights to associate and take collective action as being of 'a fundamental character within the Community legal order, as the Charter of Fundamental Rights of the European Union reaffirms'. ${ }^{51}$ At the June Summit, two other States, Poland and Ireland, reserved their right to join this Protocol. In addition, Poland also entered a unilateral declaration, to the effect that the Charter 'does not affect in any way the right of Member States to legislate in the sphere of public morality, family

50 Opinion of AG Maduro in Case C-438/05 International Transport Workers' Federation and the Finnish Seamen's Union $v$ Viking Line ABP and OÜ Viking Line Eesti (23 May 2007); and Opinion of AG Mengozzi in Case C-341/05 Laval un Partneri Ltd v Svenska Byggnadsarbetareförbundet and others (23 May 2007).

51 Viking Line (n 50) para 60. 
law as well as the protection of human dignity and the respect for human physical and moral integrity'.

It will remain to be seen how successful such moves are in restricting the Court in its use of the Charter and the development of its human rights jurisprudence. Certainly, there is nothing legally to stand in the way of the Court pursuing fundamental rights protection and interpretation through the route of general principles, rather than explicitly under the Charter. Indeed, save in a small number of exceptional cases, and despite invitations from Advocates General, ${ }^{52}$ litigants, and others presenting their observations, the Court has been careful to restrict its reliance on the Charter in its jurisprudence to date, ${ }^{53}$ preferring instead to locate exclusively the source of fundamental rights in the EU order as general principles drawn from the common constitutional traditions of the Member States, and sources such as the European Convention of Human Rights. This has recently been seen in respect of the Court's recognition of a general principle of non-discrimination on the grounds of age, in Mangold,${ }^{54}$ a case with consequences not simply for national labour law, but significant also in that the Court held that the principle of consistent interpretation of national legislation with EU law would apply before the transposition period of relevant directive had passed.

\section{4: The End of Judicial Constitutionalisation?}

According to an accepted view of the integration process, during periods in the Union's history when the political dimension has been stalled, the European Court had stepped in, delivering judgments which have further developed - indeed federalised- the legal order, and maintained the integrative momentum. Could we expect the Court do so again during the current period of constitutional limbo and political uncertainty? It could be suggested that the Court may be increasingly wary of taking such a lead, given the complicated political environment that it operates within, the lessons learnt from the past that its constitutionalised doctrines do not always gain unqualified support and acceptance, and with new levels of opposition from within some of the new Member State

\footnotetext{
52 Sometimes particularly forcibly: in his opinion in Case C-303/05 Advocaten voor de Wereld $v$ Leden van de Ministerrad (3 May 2007), for example, AG Ruiz-Jarabo Colomer argued that 'the Court must break its silence and recognise the authority of the Charter of Fundamental Rights as an interpretative tool at the forefront of the protection of the fundamental rights which are part of the heritage of the Member States' (para 79).

53 Including it as an additional source confirming the status of fundamental rights in Case C-540/03 Parliament $v$ Council [2006] ECR I-576; Case C-303/05 Advocaten voor de Wereld $v$ Leden van de Ministerrad (3 May 2007); Case C-432/05 Unibet Ltd $v$ Justititekanslern (13 March 2007).

54 Case C-144/04 Mangold v Helm [2005] ECR I-9981.
} 
orders. On one level, recent activities of the Court would tend to support the first view. As Mangold demonstrates, during the period of formal constitutional uncertainty, the Court has continued to hand down judgments of constitutional significance. A particularly notable contribution over recent years has been the Court's rulings which have seen it extend principles developed in the Community pillar across the three pillar structure, moving some way towards bringing a unifying coherence to the fragmented legal orders.

At issue in Pupino ${ }^{55}$ was the interpretation of national, Italian law on procedural protections offered to victims in criminal trials. Under national law, a special regime for the giving of evidence was available to alleged child sex abuse victims, enabling them to give evidence away from the Court. Council Framework Decision 2001/220/JHA ${ }^{56}$ on the standing of victims in criminal proceedings however provides that States should ensure special treatment is made available for all victims who are "particularly vulnerable'. The victims in the national criminal trial - all children - had allegedly been abused by a school teacher, but not sexually. Could they nonetheless take advantage of the provisions in the Framework Decision when giving their evidence? Under Article 34(2)(b) TEU, Framework Decisions are defined as being 'binding upon the Member States as to the result to be achieved but shall leave to the national authorities the choice of forms and methods'. This article further explicitly provides that these measures 'shall not entail direct effect'. As such, the national law could not simply be substituted by the EU provision. Nonetheless, and in opposition to some of the views presented by Member States in the case, the Court of Justice considered it possible to read across the principle of indirect effect, or consistent interpretation, from the EC order into the Police and Judicial Co-operation pillar. Identifying the significant similarities between directives and framework decisions, and overcoming the formal absence of an Article 10 EC duty of loyal cooperation in the TEU provisions, the Court reasoned that:

It would be difficult for the Union to carry out its task effectively if the principle of loyal cooperation, requiring in particular that Member States take all appropriate measures, whether general or particular, to ensure fulfilment of their obligations under European Union law, were not also binding in the area of police and judicial cooperation in criminal matters. ${ }^{57}$

55 Case C-105/03 Pupino [2005] ECR I-5285.

56 [2001] OJ L82/1.

57 Pupino (n 55) para 42. 
Meanwhile, in Dell'Orto, ${ }^{58}$ the Court was presented with a request for a preliminary ruling from an Italian court, again on the scope of Framework Decision 2001/220/JHA, this time on whether legal, as well as natural persons are covered by its terms when they are the victims of alleged crimes. Rather than being brought under Article 35 TEU, which provides the basis for preliminary rulings under the third pillar, the referring court had used the Article 234 EC procedure. However, according to the Court, which appeared to draw interpretative strength from the unifying dimensions of its Pupino judgment,

the fact that the order for reference does not mention Article $35 \mathrm{EU}$, but refers to Article $234 \mathrm{EC}$, cannot of itself make the reference for preliminary ruling inadmissible. This conclusion is reinforced by the fact that the Treaty on European Union neither expressly nor by implication lays down the form in which the national court must present its reference for a preliminary ruling. ${ }^{59}$

Finally, in Gestoras Pro Amnistia, ${ }^{60}$ the Court was asked to fill the gaps in the legal order to enable an action in damages to be brought by litigants affected by EU measures adopted outside the Community framework. The Basque group Gestoras Pro Amnistia had, it alleged, been wrongly identified as a terrorist group in an annex to a Council Common Position on the application of certain measures to combat terrorism, ${ }^{61}$ and had subsequently suffered damage through the freezing of its assets, for which it sought redress. The Common Position had been adopted jointly on the CFSP basis of Article 15 TEU and Article 34 TEU, the Police and Judicial Co-operation pillar. A Council declaration at the time of the adoption of the Common Position provided that in the event of any error in respect to those on the list, the injured party had the right to seek judicial redress. An action in damages before the CFI had been thrown out, ${ }^{62}$ and indeed, the Court of Justice agreed that no action in damages could stand - Article 35 TEU did not grant it jurisdiction to hear actions in damages. However, Article 35 TEU also excludes jurisdiction of the Court over common positions. Nonetheless, the Court ruled that this exclusion was based on the assumption that common positions were without binding legal effects for third parties. Where this assumption was wrong, and the measure had binding legal effects, it could come before

58 Case 467/05 Dell'Orto (28 June 2007).

59 Ibid para 36.

60 Case C-354/04 P Gestoras Pro Amnistia and others v Council (27 February 2007).

61 2001/931/CFSP [2001] OJ L344/1.

62 Case T-333/02 Gestoras Pro Amnistia and others $v$ Council, Order of 7 June 2004 [2004] OJ C228/40. 
the Court, regardless of its nomenclature. The Court relied on case law from the Community pillar to make this point:

The right to make a reference to the Court for a preliminary ruling must therefore exist in respect of all measures adopted by the Council, whatever their nature or form, which are intended to have legal effects in relation to third parties (see, by analogy, Case 22/70 Commission v Council (ERTA) [1971] ECR 263, paragraphs 38 to 42, and Case C-57/95 France v Commission [1997] ECR I-1627, paragraph 7 et seq.). ${ }^{63}$

Equally, despite their apparent exclusion from Article 35(6) TEU, common positions with legal effects could be subject to action in annulments brought by the Commission or by the Member States.

This case law may thus present a view of the Court taking its first steps towards unifying the legal orders of the fragmented pillars around a Community legal logic, and they would seem to accord with a view of the Court as constitutional hero, pushing forward the integration process whilst it is stalled through other routes. As Fletcher reports for example, 'as the EU faces yet another political crisis following the failure of the constitutional treaty, the European Court of Justice has boldly stepped in to flex its transformative muscles once again'. ${ }^{64}$ Certainly, a legal narrative could continue to be employed that reifies the role of the Court, that accords a central role to it in pushing forward constitutionalisation. And an argument could be advanced that there was a certain inevitability to these decisions, that the law has its own path dependent logic, in that earlier decisions, and the bases on which they were taken have consequences which flowed inexorably to these rulings, and beyond.

However, I would suggest that we need to be cautious about accepting this view of an inherently integrative legal order. Certainly, it cannot be ignored that the Court operates as a legal institution, and as such, reasoning by analogy is recognised as an appropriate interpretative approach, and the doctrine of precedence is an important feature, but to simply accept that there is a certain inevitability to these judgments, and any continued constitutionalisation of the other pillars, would be to write out all sense of agency in the legal order. On any one point, the Court will be faced with a range of legally arguable views, all presented as the natural consequences of the previous case law, such is the nature of legal argumentation. These views may be internal to the judicial process itself, as presented by Advocates General, by the parties to the case, and

63 Gestoras Pro Amnistia para 53.

64 M Fletcher, 'Extending "Indirect Effect" to the Third Pillar: The Significance of Pupino' (2005) EL Rev 862, 877. 
by those providing observations. The perspectives of the Commission's Legal Service presented as observations may prove a valuable resource (the results in Mangold and Pupino both appear to accord with the approach favoured by the Commission, for example), and the composition of the Court may also be significant. The Court will also be participating in a wider, iterative learning process, drawing on signals from other institutions and national courts to determine what may be considered appropriate and legitimate, through both internal and external perspectives. Such an explanation may for example be seen as one of the causes of the Court's continued refusal to accord horizontal direct effects to directives. Equally, it may learn that national court support is not wholehearted for its reading across of Community pillar norms and principles into other areas, ${ }^{65}$ and should wait for formal developments to take place through Member State reform of the Treaty framework. There is much to be said of Ross's argument that 'effectiveness is emerging as the driver of constitutional evolution': ${ }^{66}$ its language and logic lies explicitly within many of these cases, indeed, it appears as something of a justificatory 'institutional mantra', ${ }^{67}$ however, there are clear limits to what the Court recognises it can achieve in the name of effectiveness.

\section{Conclusion}

Amongst its many functions, the Court has a significant role in conducting constitutional review, a role which extends across the pillars of the EU. It reviews the constitutionality of EU measures, and holds the Member States to account for their respect for EU law, both directly, under actions brought according to the 226-228 EC enforcement procedure, and indirectly, through Article 234 EC. The Court's powers are strongly developed in respect to Community law, and it is currently taking steps to develop its assigned role in relation to measures currently under the third pillar. Thus, it is generally accepted that the Court has constitutionalised the EC Treaty, and is now undertaking a comparable project in relation to elements of the EU Treaty. In this article, it has been argued that to the extent that constitutionalisation has been undertaken by the

65 See, for example, the judgment of the German Constitutional Court in the review of the constitutionality of the national implementation of the European Arrest Warrant regime, 2 BvR 2236/04, which emphasises the 'public international law' status of the third pillar, and leaves an 'eloquent silence' on the issue of its interpretative obligations under Pupino; H Satzger and T Pohl, 'The German Constitutional Court and the European Arrest Warrant: Cryptic Signals from Karlsruhe' (2006) 4 Journal of International Criminal Justice 686, 695. See also J Komarek, 'European Constitutionalism and the European Arrest Warrant: In Search of the Limits of "Contrapunctual Principles"” (2007) 44 CML Rev 9.

66 M Ross, 'Effectiveness in the European Legal Order(s): Beyond Supremacy to Constitutional Proportionality’ (2006) 31 EL Rev 476.

67 Ibid 480. 
Court, it has done so, and could continue to do so only with the support of a range of legal and political actors. The constitutionalised Treaty according to the Court does not necessarily have the same qualities when viewed from the perspective of the Member State. It has questioned the assumption of an inherently integrative logic questioned, and this appears more pertinent today, with the proposed Reform Treaty containing provisions which would seem to act as a potential brake on the assumed drive to 'ever closer union' - such as the acknowledgement that competences may be handed back to Member States, and States may withdraw from the Union. This feature is one of many aspects of the complex context within which the Court must operate. In the final analysis, we could broadly expect the Court, charged with task of ensuring law is observed, to seek to take such steps as a necessary to promote the effectiveness of the legal order, within the limits of the Treaty, and to the extent that it can rely on a sufficient basis of support for its interpretations of the law. Reliance on an assumed respect for, and acceptance of, legal rulings simply because they have the quality of law may prove misplaced. 